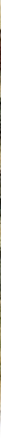

\title{
RESPONSABILIDADE CIVIL PELO TRATAMENTO DE DADOS PESSOAIS NA LEI GERAL DE PROTEÇÃO DE DADOS
}

\section{CIVIL LIABILITY FOR THE PROCESSING OF PERSONAL DATA IN THE GENERAL DATA PROTECTION LAW}

\author{
Camila Ferrão dos Santos ${ }^{1}$ \\ Jeniffer Gomes da Silva ${ }^{2}$ \\ Vinicius Padrão ${ }^{3}$
}

RESUMO: A Lei Geral de Proteção de Dados (Lei Federal n 13.709/2018, “LGPD”) incorpora, ao ordenamento jurídico brasileiro, diversos instrumentos para garantir a proteção de dados pessoais, proporcionando um maior controle aos titulares de seus dados ao assegurar mais transparência e segurança ao longo de toda a cadeia de tratamento. A LGPD estabelece também as consequências jurídicas nas hipóteses em que dados pessoais são tratados em desconformidade com suas disposições. Dentre essas consequências, interessa-nos, para os fins do presente trabalho, a responsabilização civil dos agentes de tratamento, na medida em que a LGPD não foi explícita ao definir o regime de responsabilidade civil aplicável. Nesse sentido, do ponto de vista metodológico, o presente artigo se propõe a apresentar esta discussão considerando os dispositivos aplicáveis da LGPD e, na sequência, expor, à luz da doutrina jurídica, os principais argumentos, por um lado, daqueles que sustentam que o regime aplicável é o da responsabilidade subjetiva e, por outro lado, da corrente que defende a responsabilização objetiva dos agentes de tratamento. Os objetivos do presente artigo são, pois, consolidar os principais argumentos que permeiam a discussão sobre a responsabilidade civil dos agentes de tratamento e apresentar diretrizes para o melhor enquadramento da temática à luz do ordenamento jurídico pátrio.

Palavras-CHAVe: Proteção de dados. Tratamento de dados. Responsabilidade objetiva. Responsabilidade subjetiva.

ABSTRACT: The General Data Protection Law (Federal Law No. 13.709/18, "LGPD") incorporates, into the Brazilian legal framework, several instruments to ensure the protection of personal data, providing control to the data subjects of their data by ensuring more transparency and security throughout the entire data processing chain. The LGPD also establishes the legal consequences in cases where personal data is processed in breach of its provisions. Among these consequences, for the purposes of this article, we are interested in the civil liability of processing agents, as the LGPD was not explicit in defining the applicable civil liability regime. In this sense, this article proposes to present this discussion, exposing the main arguments, on the one hand, of those who argue that the applicable regime is the subjective civil

\footnotetext{
${ }^{1}$ Mestranda em Direito Civil pela Universidade do Estado do Rio de Janeiro (UERJ). Advogada. Membro da Comissão de Direito Civil da OAB/RJ. E-mail: camilafdsantos@ gmail.com.

${ }^{2}$ Mestranda em Direito Civil pela Universidade do Estado do Rio de Janeiro (UERJ). Advogada. Pesquisadora da Clínica de Responsabilidade Civil da Faculdade de Direito da UERJ (UERJ resp). E-mail: jen.gomesdasilva@gmail.com.

${ }^{3}$ Mestrando em Direito Civil pela Universidade do Estado do Rio de Janeiro (UERJ). Advogado. Pesquisador do Instituto de Tecnologia e Sociedade do Rio de Janeiro (ITS Rio). E-mail: viniciusjpadrao@gmail.com.
} 
responsibility and, on the other hand, of the current that defends the objective civil liability of processing agents. The aim of this article is, therefore, to consolidate the main arguments involving the discussion about the civil liability of treatment agents and to present guidelines for the best framing of the theme in the Brazilian legal system.

KEYWORDS: Data protection. Data processing. Strict liability. Subjective liability.

SUMÁRIO: Introdução. 1. As possíveis consequências do tratamento inadequado de dados pessoais. 2. Considerações sobre a responsabilidade civil dos agentes de tratamento à luz da LGPD. 3. Natureza jurídica da responsabilidade civil da LGPD. 3.1. Regime da responsabilidade civil subjetiva. 3.2. Regime da responsabilidade civil objetiva. 4. Conclusão. Referências.

SUMMARY: Introduction. 1 . The possible consequences of unlawful processing of personal data 2. Considerations on the civil liability of processing agents under LGPD. 3. Legal status of civil liability provided for in LGPD 3.1. Regime of subjective civil liability. 3.2. Regime of strict civil liability 4. Conclusion. References.

\section{Introdução}

Em agosto de 2015, enquanto fazia compras em um mercado próximo ao seu apartamento, L., casado e residente de bairro de classe média alta em Londres, recebeu uma ligação de sua esposa. Para sua surpresa, sua esposa o comunicou que estava pedindo divórcio, encerrando o casamento de duas décadas. Ao chegar em casa, L. foi acusado de adultério. Quando procurou entender melhor a situação, L. descobriu que seu e-mail pessoal e outros dados pessoais estavam em uma lista que foi divulgada na internet de supostos usuários do site Ashley Madison, cujo modelo de negócios consiste em possibilitar encontros extraconjugais entre cadastrados na plataforma.

Além de L., aproximadamente outros trinta milhões de usuários foram vítimas do vazamento dos bancos de dados da Ashley Madison. De acordo com as informações que foram publicizadas à época e com o pronunciamento da própria empresa ${ }^{4}$, os dados foram sequestrados por um grupo de hackers denominado "the impact team" após o grupo entender que a empresa não estava adotando as medidas necessárias para garantir a segurança das informações dos usuários. Na sequência, os dados foram divulgados pelo grupo na chamada Deep Web. Além dos e-mails dos usuários, as informações vazadas contemplavam também os seguintes dados dos usuários: nomes, senhas, endereços, números de telefone enviados pelos

\footnotetext{
${ }^{4}$ Para mais informações, conferir: <https://www.wired.com/2015/08/happened-hackers-posted-stolen-ashleymadison-data/>. Acesso em: 10 fev. 2021.
} 
usuários do site, transações realizadas na plataforma e histórico de pesquisa no site. Sobretudo por se tratar de plataforma para encontros extraconjugais, os prejuízos desse incidente de segurança não podem ser corretamente mensurados.

Todavia, incidentes de segurança envolvendo grande quantidade de dados não são uma peculiaridade de países estrangeiros. Recentemente, em território nacional, verificou-se o maior vazamento de dados pessoais do país: 220 (duzentos e vinte) milhões de pessoas tiveram seus dados pessoais divulgados indevidamente na internet. Este número supera, inclusive, a quantidade de brasileiros vivos na medida em que a lista contempla também informações sobre falecidos. Para Ronaldo Lemos, que apelidou o incidente de "vazamento do fim do mundo", "qualquer um no Brasil hoje tem de assumir que seus dados estão expostos, incluindo CPF, nome, endereço, nome dos pais, fotos de rosto, escore de crédito, participações societárias, Imposto de Renda, imóveis, números de celular, benefícios do INSS e muito mais" 5 . A origem do vazamento, contudo, ainda não foi identificada.

No mês seguinte, verificou-se outro vazamento de dados pessoais de grande proporção no país. A empresa de cibersegurança PSafe, responsável pela identificação do incidente de segurança, comunicou que informações relativas a aproximadamente 100 milhões de contas de celular foram disponibilizadas na Deep Web. De acordo com o divulgado na imprensa, os dados incluem informações sensíveis de milhões de brasileiros, incluindo o presidente Jair Bolsonaro, como tempo de duração das ligações realizadas, número de telefone, plano contratado, valor da conta, volume de minuto gastos por dia, data de nascimento e $\mathrm{CPF}^{6}$. Com efeito, incidentes de segurança envolvendo dados pessoais, sobretudo vazamento de grandes bancos de informações, não são incomuns. Também não são incomuns os compartilhamentos indevidos de dados pessoais entre empresas. Nesse sentido, sobretudo por sua sensibilidade, os estudos sobre dados pessoais sempre tiveram como norte a proteção dos mesmos ${ }^{7}$. Trata-se de preocupação compartilhada por diversos países e refletida em

\footnotetext{
5 A análise completa de Ronaldo Lemos está disponível em: <https://www1.folha.uol.com.br/colunas/ronaldolemos/2021/01/o-vazamento-de-dados-do-fim-domundo.shtml>. Acesso em: 10 fev. 2021.

${ }^{6}$ Nesse sentido, confira-se: <https://veja.abril.com.br/tecnologia/novo-vazamento-expoe-mais-de-100-milhoesde-contas-de-celular-do-brasil/amp/?_twitter_impression=true>. Acesso em: 10 fev. 2021.

${ }^{7}$ Nessa direção, seja consentido remeter a: "Antes mesmo da aprovação da LGPD, não raro se verificou a ocorrência de uma série de incidentes de segurança, que resultaram no comprometimento de milhares de informações de cunho pessoal, proporcionando prejuízos tanto patrimoniais quanto extrapatrimoniais para seus titulares. Ainda que naturalmente negativos, tais eventos auxiliaram na construção de uma cultura de proteção de dados no Brasil, haja vista que explicitam que empresas, governos e entidades da sociedade civil ainda têm muito o que fazer em termos de segurança e sigilo de dados e, por outro lado, possibilitam uma intensa divulgação do tema por meio das mídias tradicionais" (SOUZA, Carlos Affonso; PADRÃO, Vinicius. Incidentes de segurança e dever de notificação à luz da Lei Geral de Proteção de Dados. In: SOUZA, Carlos Affonso; MAGRANI, Eduardo;
} 
inúmeras regulações, como a própria General Data Protection Regulation (“GDPR”), que estabelece normas de proteção aos dados pessoais de pessoas naturais na União Europeia ${ }^{8}$. No Brasil não é diferente: a Lei Federal n 13.709/2018, em vigor desde setembro de 2020, é conhecida como Lei Geral de Proteção de Dados (“LGPD”)"

Em sua redação, a LGPD lança mão de diversos instrumentos para garantir a proteção de dados pessoais, proporcionando um maior controle aos titulares de suas informações ao assegurar mais transparência e segurança ao longo de toda a cadeia de tratamento $^{10}$. De fato, para efetiva proteção, além do controle exercido pelo próprio titular, mostra-se necessário também estabelecer balizas aos tratamentos de dados pessoais que serão realizados por terceiros ${ }^{11}$. Além de estabelecer medidas de segurança técnicas e administrativas a serem adotadas pelos agentes de tratamento ${ }^{12}$, a LGPD dispõe também sobre sanções administrativas e eventual responsabilização no âmbito civil nas hipóteses em que se verificar o tratamento de dados pessoais em desconformidade com a lei. Em outras palavras, o tratamento irregular de dados implicará, nos termos da lei, a responsabilidade dos agentes de tratamento.

A LGPD, todavia, não foi clara a respeito da natureza do regime de responsabilidade civil aplicável aos agentes de tratamento nas hipóteses de danos causados em razão da não observância de seus termos. Dessa forma, o presente artigo, sem nenhuma pretensão de esgotar a matéria, se propõe, em um primeiro momento, a apresentar e discorrer sobre os artigos da LGPD relativos à responsabilização dos agentes de tratamento. Na sequência,

SILVA, Priscila (coord.). Caderno especial: Lei Geral de Proteção de Dados (LGPD). São Paulo: Thomson Reuters Brasil, 2019, p. 214).

${ }^{8}$ A própria redação do artigo $1^{\circ}$ da GDPR deixa clara a preocupação com a proteção dos dados pessoais dos titulares. Veja-se: "1. This Regulation lays down rules relating to the protection of natural persons with regard to the processing of personal data and rules relating to the free movement of personal data. 2. This Regulation protects fundamental rights and freedoms of natural persons and in particular their right to the protection of personal data. 3. The free movement of personal data within the Union shall be neither restricted nor prohibited for reasons connected with the protection of natural persons with regard to the processing of personal data".

${ }^{9}$ Destaca-se, inclusive, que, após a alteração promovida pela Lei Federal no ${ }^{\circ} 13.853 / 2019$, a ementa da Lei Federal no 13.709/2018 teve sua redação modificada para "Lei Geral de Proteção de Dados Pessoais (LGPD).".

${ }^{10}$ À luz da LGPD, tratamento de dados pessoais é definido como "toda operação realizada com dados pessoais, como as que se referem a coleta, produção, recepção, classificação, utilização, acesso, reprodução, transmissão, distribuição, processamento, arquivamento, armazenamento, eliminação, avaliação ou controle da informação, modificação, comunicação, transferência, difusão ou extração." (Artigo $5^{\circ}, \mathrm{X}$ ).

${ }^{11}$ Danilo Doneda assevera que "a mera atuação do indivíduo para a proteção de seus interesses - o controle individual, como ocorre em algumas das concepções de proteção de dados pessoais que nós verificamos - não é capaz de projetar uma situação na qual o direito fundamental em questão receba a tutela adequada e acaba por espelhar uma determinada concepção ideológica dos interesses em questão que, amenizada por uma aparente concessão de poder ao indivíduo, não acarreta na tutela efetiva de seus interesses". DONEDA, Danilo. Da privacidade à proteção de dados. Rio de Janeiro: Renovar, 2006, p. 399.

${ }^{12}$ Segundo a LGPD, são "agentes de tratamento de dados" o controlador, pessoa natural ou jurídica, de direito público ou privado, a quem competem as decisões referentes ao tratamento de dados pessoais (art. $5^{\circ}$, VI), e o operador, pessoa natural ou jurídica, de direito público ou privado, que realiza o tratamento de dados pessoais em nome do controlador (art. $5^{\circ}$, VII). 
como resultado das pesquisas realizadas, o artigo apresentará os principais argumentos, por um lado, daqueles que sustentam que o regime aplicável é o da responsabilidade subjetiva e, por outro, da corrente que defende a responsabilização objetiva dos agentes de tratamento - o que será feito a partir da metodologia civil-constitucional, com a análise da doutrina, legislação e jurisprudência pátrias sob a ótica dos princípios e valores constitucionais.

\section{As possíveis consequências do tratamento inadequado de dados pessoais}

Em termos gerais, nas hipóteses em que houver o tratamento de dados pessoais em desconformidade com a LGPD, os agentes de tratamento poderão estar sujeitos às seguintes penalidades: (i) ações indenizatórias individuais; (ii) ações indenizatórias coletivas; (iii) sanções administrativas por parte de órgãos de proteção ao consumidor; ou ainda (iv) sanções administrativas aplicadas pela Autoridade Nacional de Proteção de Dados ("ANPD"). Dessa forma, especialmente quanto à responsabilidade dos agentes de tratamento, é importante destacar que o tratamento irregular dos dados não proporciona apenas responsabilidade no âmbito civil.

Nesse sentido, a LGPD estabelece que os agentes de tratamento, em razão de infrações à LGPD, estarão sujeitos a sanções administrativas aplicáveis pela Autoridade Nacional de Proteção de Dados. A ANPD é a principal entidade responsável por garantir a proteção dos dados pessoais no Brasil, na medida em que é o único órgão competente para aplicar as sanções administrativas previstas no art. 52 da LGPD ${ }^{13}$. Confira-se o dispositivo em questão:

\footnotetext{
Art. 52. Os agentes de tratamento de dados, em razão das infrações cometidas às normas previstas nesta Lei, ficam sujeitos às seguintes sanções administrativas aplicáveis pela autoridade nacional: I - advertência, com indicação de prazo para adoção de medidas corretivas; II - multa simples, de até $2 \%$ (dois por cento) do faturamento da pessoa jurídica de direito privado, grupo ou conglomerado no Brasil no seu último exercício, excluídos os tributos, limitada, no total, a $\mathrm{R} \$ 50.000 .000,00$ (cinquenta milhões de reais) por infração;

III - multa diária, observado o limite total a que se refere o inciso II; IV - publicização da infração após devidamente apurada e confirmada a sua ocorrência; $\mathrm{V}$ - bloqueio dos dados pessoais a que se refere a infração até a sua regularização; VI - eliminação dos dados pessoais a que se refere a infração;
}

\footnotetext{
${ }^{13}$ As sanções administrativas previstas no art. 52 da LGPD só entram em vigor no dia $1^{\circ}$ de agosto de 2021. É esta a redação do art. 65, I-A, da LGPD. Veja-se: “Art. 65. Esta Lei entra em vigor: (...) I-A - dia $1^{\circ}$ de agosto de 2021, quanto aos arts. 52, 53 e 54".
} 
$\mathrm{X}$ - suspensão parcial do funcionamento do banco de dados a que se refere a infração pelo período máximo de 6 (seis) meses, prorrogável por igual período, até a regularização da atividade de tratamento pelo controlador; (Incluído pela Lei $\mathrm{n}^{\circ}$ 13.853 , de

2019)

XI - suspensão do exercício da atividade de tratamento dos dados pessoais a que se refere a infração pelo período máximo de 6 (seis) meses, prorrogável por igual período; (Incluído pela Lei $\mathrm{n}^{\circ}$ 13.853, de 2019) XII - proibição parcial ou total do exercício de atividades relacionadas a tratamento de dados. (Incluído pela Lei no 13.853, de 2019)

Dessa forma, os titulares dos dados pessoais poderão reivindicar o cumprimento de seus direitos junto à ANPD (Art. 18, § 1, LGPD ${ }^{14}$ ). Além disso a própria LGPD estabelece que os direitos dos titulares também poderão ser exercidos perante órgãos de defesa do consumidor (Artigo $18, \S 8^{\circ}, \mathrm{LGPD}^{15}$ ), sendo certo que a ANPD coordenará as suas atividades com outras entidades e órgãos com poderes sancionatórios relacionados com a proteção de dados pessoais, como é o caso das entidades de defesa do consumidor, que também têm poderes sancionatórios no âmbito do Código de Defesa do Consumidor (CDC).

Com efeito, a própria LGPD, em seu art. $52, \S 2^{\circ}$, estabelece que "[o] disposto neste artigo não substitui a aplicação de sanções administrativas, civis ou penais definidas na Lei $\mathrm{n}^{\circ}$ 8.078, de 11 de setembro de 1990, e em legislação específica”. Dessa forma, nas hipóteses em que houver uma relação de consumo entre o agente de tratamento e os titulares, o tratamento ilícito de dados pessoais poderá ensejar a aplicação das sanções administrativas previstas no art. 56 do Código de Defesa do Consumidor ${ }^{16}$. Veja-se:

Art. 56. As infrações das normas de defesa do consumidor ficam sujeitas, conforme o caso, às seguintes sanções administrativas, sem prejuízo das de natureza civil, penal e das definidas em normas específicas:

I - multa;

II - apreensão do produto;

III - inutilização do produto;

IV - cassação do registro do produto junto ao órgão competente;

$\mathrm{V}$ - proibição de fabricação do produto;

VI - suspensão de fornecimento de produtos ou serviço;

VII - suspensão temporária de atividade;

VIII - revogação de concessão ou permissão de uso;

\footnotetext{
14 “Art. 18 (...) $\S 1^{\circ} \mathrm{O}$ titular dos dados pessoais tem o direito de peticionar em relação aos seus dados contra o controlador perante a autoridade nacional".

15 “Art. 18 (...) $\S 8^{\circ} \mathrm{O}$ direito a que se refere o $\S 1^{\circ}$ deste artigo também poderá ser exercido perante os organismos de defesa do consumidor".

${ }^{16}$ Cumpre mencionar que o Código de Defesa do Consumidor prevê também sanções penais para atividades ilícitas que, de alguma forma, envolvem o tratamento de dados pessoais: "Art. 72. Impedir ou dificultar o acesso do consumidor às informações que sobre ele constem em cadastros, banco de dados, fichas e registros: Pena Detenção de seis meses a um ano ou multa."; e "Art. 73. Deixar de corrigir imediatamente informação sobre consumidor constante de cadastro, banco de dados, fichas ou registros que sabe ou deveria saber ser inexata: Pena Detenção de um a seis meses ou multa."
} 
IX - cassação de licença do estabelecimento ou de atividade;

$\mathrm{X}$ - interdição, total ou parcial, de estabelecimento, de obra ou de atividade;

XI - intervenção administrativa;

XII - imposição de contrapropaganda.

Parágrafo único. As sanções previstas neste artigo serão aplicadas pela autoridade administrativa, no âmbito de sua atribuição, podendo ser aplicadas cumulativamente, inclusive por medida cautelar, antecedente ou incidente de procedimento administrativo.

Estas sanções administrativas já eram inclusive aplicadas antes mesmo da entrada em vigor da Lei Geral de Proteção de Dados. Em 2019, por exemplo, o Ministério da Justiça e Segurança Pública, por meio da Secretaria Nacional do Consumidor ("Senacon”), aplicou ao Facebook multa no valor de aproximadamente seis milhões de reais pelo compartilhamento indevido de dados de usuários ${ }^{17}$. De acordo com as informações divulgadas pela Senacon, a investigação começou após suspeita de que o escândalo Cambridge Analytica poderia ter afetado usuários brasileiros. Ao final do processo administrativo, entendeu-se que houve prática abusiva do Facebook. Nessa mesma direção, em 2014, a operadora de telefonia Oi também foi multada em três milhões e meio de reais pela Senacon por suposto mapeamento do tráfego de seus consumidores na Internet, que, em momento posterior, era comercializado com agências de publicidade ${ }^{18}$.

No âmbito civil, a Seção III da LGPD ("Da responsabilidade e do Ressarcimento de Danos") apresenta os principais dispositivos relacionados à responsabilidade civil nas hipóteses de tratamento inadequado de dados pessoais. Todavia, a LGPD não foi explícita quanto ao regime de responsabilização adotado, deixando na mão da literatura jurídica e da jurisprudência definir se a responsabilidade dos agentes de tratamento pelos danos oriundos do tratamento em desconformidade com a LGPD é subjetiva ou, ao contrário, objetiva. Nas palavras de Gisela Sampaio, "A LGPD deveria ter sido explícita em relação à natureza da responsabilidade, porque isso evitaria uma série de controvérsias que, inevitavelmente, vão surgir em razão dessa falta de clareza" ${ }^{19}$. Os principais argumentos de cada uma das correntes

\footnotetext{
17 Disponível em: <https://valor.globo.com/empresas/noticia/2019/12/30/ministrio-da-justia-aplica-multa-de-r66-milhes-ao-facebook.ghtml>. Acesso em: 11 fev. 2021.

18 “O Departamento de Proteção e Defesa do Consumidor (DPDC), órgão da Secretaria Nacional do Consumidor (Senacon/MJ), iniciou investigações, em 2010, a partir de informações de que a parceria da Oi com a empresa britânica Phorm, consistia no desenvolvimento do software "Navegador", que mapeava o tráfego de dados do consumidor na internet de modo a compor seu perfil de navegação. Tais perfis, segundo o DPDC, eram comercializados com anunciantes, agências de publicidade e portais da web, para ofertar publicidade e conteúdo personalizados a esses consumidores." Mais informações em: <https:/oglobo.globo.com/economia/defesa-doconsumidor/oi-multada-em-35-milhoes-por-invasao-de-privacidade-feita-por-velox-13348505>. Acesso em: 11 fev. 2021.

${ }^{19}$ SAMPAIO, Gisela. Regime de responsabilidade adotado pela lei de proteção de dados brasileira. In: SOUZA, Carlos Affonso; MAGRANI, Eduardo; SILVA, Priscila (coord.). Caderno especial: Lei Geral de Proteção de Dados (LGPD). São Paulo: Thomson Reuters Brasil, 2019, p. 169.
} 
serão oportunamente explorados no presente artigo.

\section{Considerações sobre a responsabilidade civil dos agentes de tratamento à luz da}

\section{LGPD}

Em primeiro momento, mostra-se necessário circunscrever o âmbito de aplicação do regime de responsabilidade civil previsto na Lei Geral de Proteção de Dados. Em outras palavras, deve-se verificar em quais situações será pertinente a discussão sobre a falta de clareza da LGPD quanto à natureza do regime de responsabilidade. Nesse sentido, merece atenção o art. 45 da LGPD, segundo o qual "as hipóteses de violação do direito do titular no âmbito das relações de consumo permanecem sujeitas às regras de responsabilidade previstas na legislação pertinente". Sobre o tema, a melhor doutrina assevera que "[a]s regras sobre responsabilidade civil da LGPD ficam reservadas às relações sem hipossuficiência entre as partes ou àquelas em que não há exploração de atividade comercial, como nas relações entre associações e associados e entre condomínios e condôminos"20.

Com efeito, conforme estabelece o art. 14 do Código de Defesa do Consumidor ${ }^{21}$, a responsabilidade civil, nas hipóteses em que houver uma relação de consumo entre o agente de tratamento e o titular dos dados, será de natureza objetiva. Isto é, nesses cenários, caso haja um tratamento ilícito de dados pessoais e, consequentemente, um dano aos titulares, o dever de indenizar surgirá independentemente da identificação de conduta culposa por parte do agente de tratamento. Este verdadeiro diálogo de fontes já tem sido inclusive aplicado pela jurisprudência pátria. Ao avaliar o compartilhamento indevido de dados pessoais por imobiliária com terceiros alheios à relação contratual, o TJSP entendeu que a responsabilidade é objetiva. Veja-se:

Isto posto, a responsabilidade da ré é objetiva (arts. 14, caput, CDC e 45, LGPD). Inexiste suporte para a exclusão de responsabilidade (art. 14, $\S 3^{\circ}$, I a III, CDC), de sorte que caracterizado o ato ilícito relativo a violação a direitos de personalidade do autor, especialmente por permitir e tolerar (conduta omissiva) ou mesmo promover (conduta comissiva) o acesso indevido a dados pessoais do requerente por terceiros. Irrelevante se a ré possui mecanismos eficazes para a proteção de dados, seja porque

\footnotetext{
${ }^{20}$ KONDER, Carlos Nelson; LIMA, Marco Antônio de Almeida. Responsabilidade civil dos advogados no tratamento de dados à luz da Lei no 13.709/2018. In: EHRHARDT JÚNIOR, Marcos et al. (coord.). Direito civil e tecnologia. Belo Horizonte: Fórum, 2020, p. 421.

${ }^{21}$ Veja-se a redação do dispositivo: "Art. 14. O fornecedor de serviços responde, independentemente da existência de culpa, pela reparação dos danos causados aos consumidores por defeitos relativos à prestação dos serviços, bem como por informações insuficientes ou inadequadas sobre sua fruição e riscos."
} 
se sujeita às normas consumeristas em relação à sua responsabilidade, bem como pelo fato de que houve utilização indevida dos dados do requerente em decorrência do contrato firmado entre as partes. Sendo a responsabilidade objetiva, não há suporte para se inquirir a existência de culpa ou a presença de suas modalidades (imperícia, negligência ou imprudência). ${ }^{22}$ (Grifou-se)

A controvérsia da natureza jurídica do regime de responsabilidade fica restrita, pois, às situações em que não existe uma relação de consumo entre o titular e os agentes de tratamento na medida que, nesses casos, prevalece o regime de responsabilidade previsto no Código de Defesa do Consumidor. O regime da LGPD, em última instância, apresenta um papel residual, sendo aplicável, por exemplo, nas relações entre associações e associados ou ainda entre empregadores e empregados. A preocupação com a responsabilização dos agentes de tratamento está presente na lei desde a enumeração dos princípios da LGPD, sobretudo quando esta determina que as atividades de tratamento deverão observar, dentre outros, os princípios da segurança $a^{23}$, da prevenção $0^{24}$ e da responsabilização ${ }^{25}$. Estes princípios, como será exposto ao longo do presente trabalho, influenciam todo o arcabouço regulatório de proteção de dados inaugurado pela LGPD.

Especificamente em relação ao regime previsto na lei, o artigo 42 da Lei estabelece que "O controlador ou o operador que, em razão do exercício de atividade de tratamento de dados pessoais, causar a outrem dano patrimonial, moral, individual ou coletivo, em violação à legislação de proteção de dados pessoais, é obrigado a repará-lo”. Com o intuito de ampliar as hipóteses de reparação das vítimas, a LGPD esclarece as duas hipóteses nas quais a responsabilidade civil pelos danos será solidária. A primeira delas é a solidariedade entre o controlador e o operador, na hipótese em que este "descumprir as obrigações da legislação de proteção de dados ou quando não tiver seguido as instruções lícitas do controlador" (Art. 42, $\left.\S 1^{\circ}, I\right)$. Por sua vez, a segunda hipótese de solidariedade será verificada em que dois ou mais controladores estiverem diretamente envolvidos no tratamento dos dados pessoais (Art. 42, § $\left.1^{\mathrm{o}}, \mathrm{II}\right)$.

\footnotetext{
${ }^{22}$ Tribunal de Justiça do Estado de São Paulo. Processo n $n^{o}$ 1080233-94.2019.8.26.0100. Juiz Tonia Koroku. $13^{\text {a }}$ Vara Cível. Julgamento em 29.09.2020.

23 “Art. $6^{\circ}$. As atividades de tratamento de dados pessoais deverão observar a boa-fé e os seguintes princípios: (...) VII - segurança: utilização de medidas técnicas e administrativas aptas a proteger os dados pessoais de acessos não autorizados e de situações acidentais ou ilícitas de destruição, perda, alteração, comunicação ou difusão".

24 “Art. $6^{\circ}$. As atividades de tratamento de dados pessoais deverão observar a boa-fé e os seguintes princípios: (...) VIII - prevenção: adoção de medidas para prevenir a ocorrência de danos em virtude do tratamento de dados pessoais".

25 “Art. $6^{\circ}$. As atividades de tratamento de dados pessoais deverão observar a boa-fé e os seguintes princípios: (...) $\mathrm{X}$ - responsabilização e prestação de contas: demonstração, pelo agente, da adoção de medidas eficazes e capazes de comprovar a observância e o cumprimento das normas de proteção de dados pessoais e, inclusive, da eficácia dessas medidas.".
} 
Na sequência, o artigo 43 elucida as excludentes de responsabilidade dos agentes de tratamento. À luz do dispositivo, os agentes de tratamento só não serão responsabilizados quando provarem que: (i) não realizaram o tratamento de dados pessoais que lhes é atribuído; (ii) embora tenham realizado o tratamento de dados pessoais que lhes é atribuído, não houve violação à legislação de proteção de dados; ou (iii) o dano é decorrente de culpa exclusiva do titular dos dados ou de terceiro. Após, o artigo 44 esclarece as hipóteses de tratamento irregular dos dados. Veja-se:

Art. 44. O tratamento de dados pessoais será irregular quando deixar de observar a legislação ou quando não fornecer a segurança que o titular dele pode esperar, consideradas as circunstâncias relevantes, entre as quais:

I - o modo pelo qual é realizado;

II - o resultado e os riscos que razoavelmente dele se esperam;

III - as técnicas de tratamento de dados pessoais disponíveis à época em que foi realizado.

Parágrafo único. Responde pelos danos decorrentes da violação da segurança dos dados o controlador ou o operador que, ao deixar de adotar as medidas de segurança previstas no art. 46 desta Lei, der causa ao dano.

Nota-se, portanto, que o legislador efetivamente optou por não explicitar o regime de responsabilidade aplicável. Apesar das críticas nesse sentido, a doutrina elogia a técnica legislativa ao não definir taxativamente o que poderia ser considerado dano no âmbito da LGPD, permitindo que seja feita uma avaliação casuística levando em consideração as peculiaridades do caso concreto ${ }^{26}$.

\section{Natureza jurídica da responsabilidade civil da LGPD}

Como supramencionado, em razão da ausência de clareza do legislador sobre a matéria, existe ampla controvérsia na doutrina - com relevantes argumentos para todos os lados - acerca da natureza da responsabilidade civil dos agentes de tratamento de dados adotada pela LGPD.

Nesse cenário, destacam-se duas correntes doutrinárias principais: a primeira, vinculada à responsabilidade civil objetiva, entende que a caracterização da responsabilidade

\footnotetext{
${ }^{26}$ Nesse sentido, confira-se: "Já no que diz respeito aos danos, o legislador pareceu adotar boa técnica ao não apresentar nenhuma definição taxativa a respeito do que poderia ser considerado dano no âmbito da LGPD. Desse modo, estão assegurados quaisquer danos (de natureza moral ou patrimonial) que possam surgir em decorrência da violação à legislação de proteção de dados, sejam eles manifestados de maneiras já previsíveis ou não, considerando o constante avanço da tecnologia" (KONDER, Carlos Nelson; LIMA, Marco Antônio de Almeida. Responsabilidade civil dos advogados no tratamento de dados à luz da Lei no 13.709/2018. In: EHRHARDT JÚNIOR, Marcos et al. (coord.). Direito civil e tecnologia. Belo Horizonte: Fórum, 2020, p. 420).
} 
civil dependeria apenas da comprovação do dano suportado pelo titular de dados pessoais decorrente da atividade de tratamento de dados realizada por determinado agente. $\mathrm{O}$ segundo segmento doutrinário, por sua vez, defende que o dever de reparar o titular dos dados pessoais se condiciona à verificação da existência de culpa na conduta adotada pelo agente que levou à ocorrência do evento danoso.

Há, ainda, um terceiro entendimento minoritário segundo o qual, na verdade, a LGPD não teria adotado nem a responsabilidade civil objetiva, nem a responsabilidade civil subjetiva. Para essa corrente doutrinária, a LGPD tenta, essencialmente, evitar que danos sejam causados. Trata-se do regime de responsabilidade civil proativo. ${ }^{27}$ Passa-se, então, à análise dos principais argumentos utilizados pela doutrina para fundamentar a adoção do regime da responsabilidade civil subjetiva pela LGPD.

\subsection{Regime da responsabilidade civil subjetiva}

A Seção III da LGPD, intitulada "Da Responsabilidade e do Ressarcimento de Danos", traz as principais regras atinentes à responsabilidade civil que "irão reger as relações que envolvem tratamento de dados pessoais." A matéria é tratada entre os arts. 42 e 45 da lei, os quais, como observado, não deixaram evidentes a natureza da responsabilidade civil adotada pelo legislador, se objetiva ou subjetiva. ${ }^{28}$

Um primeiro argumento, de caráter formal, levantado pela corrente subjetivista diz respeito ao histórico de tramitação do projeto de lei que deu origem à LGPD. Isso porque, ao longo da tramitação, algumas menções à responsabilidade objetiva foram retiradas. Desse modo, defende-se que se o legislador tivesse o objetivo de estabelecer o regime de responsabilidade objetiva, não teria realizado essas alterações. ${ }^{29}$

Nesse contexto, os dispositivos indicados pela doutrina são os arts. 35, 42 e 44 do

\footnotetext{
${ }^{27}$ Nesse sentido, v. BODIN DE MORAES, Maria Celina. LGPD: um novo regime de responsabilização civil dito "proativo". Civilistica.com, Rio de Janeiro, ano 8, n. 3, 2019. Disponível em: <http://civilistica.com/lgpd-umnovo-regime/>. Acesso em: 25 out. 2020.

${ }^{28}$ GUEDES, Gisela Sampaio da Cruz. Regime de responsabilidade adotado pela lei de proteção de dados brasileira. In: SOUZA, Carlos Affonso et al. (coord.). Caderno especial: Lei Geral de Proteção de Dados (LGPD). São Paulo: Revista dos Tribunais, 2019, p. 169.

${ }^{29}$ Ao tratar da matéria, Carlos Nelson Konder e Marco Antônio de Almeida Lima asseveram criticamente que: "[o] último e, talvez, menos relevante argumento em favor da responsabilidade subjetiva é a aparente vontade do legislador de afastar o regime de responsabilidade objetiva. Segundo esse ponto, a versão inicial de um dos projetos apresentados sobre o tema dispunha expressamente que o regime de responsabilidade seria objetivo, vindo tal dispositivo a ser rejeitado no processo de tramitação" (KONDER, Carlos Nelson; LIMA, Marco Antônio de Almeida. Responsabilidade civil dos advogados no tratamento de dados à luz da Lei $\mathrm{n}^{\circ}$ 13.709/2018. In: EHRHARDT JÚNIOR, Marcos et al. (coord.). Direito civil e tecnologia. Belo Horizonte: Fórum, 2020, p. 423).
} 
Projeto de Lei ${ }^{\circ} 5.276$ de 2016. Confira-se:

\begin{tabular}{|c|c|c|}
\hline $\begin{array}{l}\text { Art. 35. O cedente e o } \\
\text { cessionário respondem } \\
\text { solidária e objetivamente } \\
\text { pelo tratamento de dados, } \\
\text { independentemente do } \\
\text { local onde estes se } \\
\text { localizem, em qualquer } \\
\text { hipótese. }\end{array}$ & $\begin{array}{l}\text { Art. } 42 \text {. Todo aquele que, } \\
\text { em razão do exercício de } \\
\text { atividade de tratamento de } \\
\text { dados pessoais, causar a } \\
\text { outrem dano patrimonial, } \\
\text { moral, individual ou } \\
\text { coletivo, é obrigado a } \\
\text { repará-lo. }\end{array}$ & $\begin{array}{l}\text { Art. 44. Nos casos que } \\
\text { envolvem a transferência } \\
\text { de dados pessoais, o } \\
\text { cessionário ficará sujeito às } \\
\text { mesmas obrigações legais e } \\
\text { regulamentares do cedente, } \\
\text { com quem terá } \\
\text { responsabilidade solidária } \\
\text { pelos danos eventualmente } \\
\text { causados. }\end{array}$ \\
\hline
\end{tabular}

$\mathrm{O}$ art. 35, inserido no capítulo sobre "Transferências internacionais de dados", previa regra sobre responsabilidade solidária e objetiva dos cedentes e cessionários pelos danos causados em virtude do tratamento de dados. Já o art. 42, em sua redação original, estabelecia, de forma ampla, os sujeitos obrigados a ressarcir o prejuízo. Além disso, não havia referência ao tratamento de dados realizado em violação à lei. De forma semelhante, o art. 44 também configurava outra regra ampla com o estabelecimento da solidariedade entre todos os agentes de tratamento, restando ausente distinção entre controlador e operador. ${ }^{30}$

Todas as versões posteriores do projeto, incluindo a versão sancionada da LGPD, deixaram de fazer menção, como regra geral, a um regime de solidariedade ou objetividade na responsabilidade pelos danos provenientes do tratamento de dados pessoais. Desse modo, a doutrina subjetivista assevera que a referência expressa à responsabilidade objetiva foi completamente eliminada do texto legal. Além disso, o art. 42 da LGPD passou a prever a necessidade de o dano pelo tratamento de dados ter sido oriundo da violação da legislação de proteção de dados pessoais pelos agentes de tratamento, para a incidência do dever de reparar. ${ }^{31}$

\footnotetext{
${ }^{30}$ GUEDES, Gisela Sampaio da Cruz. Regime de responsabilidade adotado pela lei de proteção de dados brasileira. In: SOUZA, Carlos Affonso et al. (coord.). Caderno especial: Lei Geral de Proteção de Dados (LGPD). São Paulo: Revista dos Tribunais, 2019, p. 174.

${ }^{31}$ Nesse sentido: "Diferentemente desse primeiro texto, todas as versões subsequentes do projeto, até a versão finalmente sancionada da LGPD, passaram a não mais mencionar, como regra geral, um regime de solidariedade ou objetividade na responsabilidade pelos danos decorrentes do tratamento de dados pessoais. A referência expressa à responsabilidade objetiva foi completamente eliminada do texto legal, bem como se introduziu, no art. 42, a necessidade de o dano pelo tratamento de dados, para fins de reparação civil, ter sido fruto da violação da legislação de proteção de dados pessoais pelos agentes de tratamento, bem como se introduziu, no art. 42, a necessidade de o dano pelo tratamento de dados, para fins de reparação civil, ter sido fruto da violação da legislação
} 
Assim, em razão desse processo de alterações legislativas e do silêncio do legislador na previsão direta da responsabilidade civil objetiva, a corrente subjetivista levanta esse primeiro argumento em prol da responsabilidade subjetiva. Verifica-se, além desse argumento de conotação formal, inúmeros outros fundamentos para a defesa de um regime de responsabilidade civil subjetiva adotado pela LGPD, como se verá adiante.

\section{a) estrutura da LGPD pautada na criação de deveres;}

Outro argumento suscitado pela corrente subjetivista é no sentido de que toda a estrutura da LGPD é pautada na criação de deveres, de modo que responsabilizar os agentes independentemente de culpa nesse sistema não faria sentido, nem do ponto de vista lógico, nem do ponto de vista jurídico. Outrossim, afirma-se que se a criação de deveres pela LGPD não seria compatível com uma responsabilização independentemente de culpa, uma vez que a lógica da responsabilidade civil objetiva é diferente, uma vez que, nesse caso, não se discute o cumprimento de deveres. ${ }^{32}$

\section{b) estabelecimento de um standard de conduta pelo legislador no capítulo dedicado à} segurança e boas práticas;

Nesse ponto, a doutrina coloca em evidência o Capítulo VII da LGPD, o qual trata "[d]a segurança e das boas práticas”. Esse capítulo se divide em duas seções ("Da segurança e do sigilo de dados" e "Das boas práticas e da governança"), nas quais a LGPD elenca inúmeros deveres que devem ser seguidos pelos agentes de tratamento de dados.

\footnotetext{
de proteção de dados pessoais pelos agentes de tratamento" (GUEDES, Gisela Sampaio da Cruz. Regime de responsabilidade adotado pela lei de proteção de dados brasileira. In: SOUZA, Carlos Affonso et al. (coord.). Caderno especial: Lei Geral de Proteção de Dados (LGPD). São Paulo: Revista dos Tribunais, 2019, p. 174).

32 "O legislador criou uma série de deveres de cuidado que devem ser seguidos pelo controlador e pelo operador, sob pena de virem a ser responsabilizados. Assim, não faz muito sentido - nem do ponto de vista lógico, nem do jurídico -, o legislador criar uma série de deveres de cuidado se não for para implantar um regime de responsabilidade subjetiva. Se o que se pretende é responsabilizar os agentes independentemente de culpa, de fato não faz sentido criar deveres a serem seguidos, tampouco responsabilizá-los quando tiverem cumprido perfeitamente todos esses deveres. A lógica da responsabilidade objetiva é outra, completamente diferente: não cabe discutir cumprimento de deveres, isto é, a responsabilidade objetiva "não decorre do descumprimento de qualquer dever jurídico", porque quando se discute cumprimento de deveres, o que no fundo está sendo analisado é se o agente atuou ou não com culpa" (GUEDES, Gisela Sampaio da Cruz. Regime de responsabilidade adotado pela lei de proteção de dados brasileira. In: SOUZA, Carlos Affonso et al. (coord.). Caderno especial: Lei Geral de Proteção de Dados (LGPD). São Paulo: Revista dos Tribunais, 2019, p. 173).
} 
Nesses dispositivos, como assevera Gisela Sampaio, o legislador teria estabelecido "verdadeiro standard de conduta que deve ser seguido pelos agentes de tratamento de dados"33, o que sugere a adoção da responsabilidade civil subjetiva pela lei, "pelo menos como regra geral". ${ }^{34}$ Os exemplos evidenciados se relacionam com a possibilidade dos agentes, dentro do âmbito de suas competências, traçarem as normas de boas práticas e de governança. Além disso, destaca-se o legislador se preocupou não só com a conduta dos agentes, como também com a adoção de processos, políticas internas, procedimentos, mecanismos de supervisão, padrões técnicos, etc. ${ }^{35}$

\section{c) a previsão do art. $6^{o}, X$ da LGPD;}

Merece menção, ainda, o disposto no art. art. $6^{\circ}$, inciso X da LGPD, o qual dispõe que as atividades de tratamento de dados pessoais devem observar o princípio da responsabilização e prestação de contas, por meio do qual o agente de tratamento deve demonstrar a "adoção de medidas eficazes e capazes de comprovar a observância e o cumprimento das normas de proteção de dados pessoais e, inclusive, da eficácia dessas medidas." Dessa forma, cabe ao agente de tratamento de dados a prestação de contas com a finalidade de "comprovar a observância e o cumprimento das normas de proteção de dados, bem como efetuar o tratamento em consonância com o consentimento dado pelo titular, sob pena de responsabilização caso haja algum dano decorrente de sua atuação". ${ }^{36}$

Por essa razão, ao interpretar esse dispositivo, Gisela Sampaio realiza a seguinte

\footnotetext{
${ }^{33}$ Neste ponto, cumpre pontuar a compreensão contemporânea de associação entre a ideia de culpa e standard de conduta: "O conceito de culpa também se encontra em estado de indefinição no atual direito da responsabilidade civil. Originalmente, culpa era apenas a atuação contrária ao direito, porque negligente, imprudente, imperita ou dolosa, que acarretava danos aos direitos de outrem. Modernamente, todavia, diversos autores abandonaram esta conceituação, preferindo considerar a culpa o descumprimento de um standard de diligência razoável, diferenciando esta noção, dita 'normativa' ou 'objetiva' da outra, dita 'psicológica'" (MORAES, Maria Celina Bodin de. Risco, solidariedade e responsabilidade objetiva. Revista dos Tribunais. v. 854, pp. 11-37, dez./2006). Nesse mesmo sentido, à luz da LGPD, v. KONDER, Carlos Nelson; LIMA, Marco Antônio de Almeida. Responsabilidade civil dos advogados no tratamento de dados à luz da Lei no 13.709/2018. In: EHRHARDT JÚNIOR, Marcos et al. (coord.). Direito civil e tecnologia. Belo Horizonte: Fórum, 2020, p. 425.

${ }^{34}$ GUEDES, Gisela Sampaio da Cruz. Regime de responsabilidade adotado pela lei de proteção de dados brasileira. In: SOUZA, Carlos Affonso et al. (coord.). Caderno especial: Lei Geral de Proteção de Dados (LGPD). São Paulo: Revista dos Tribunais, 2019, p. 175-176.

${ }^{35}$ GUEDES, Gisela Sampaio da Cruz. Regime de responsabilidade adotado pela lei de proteção de dados brasileira. In: SOUZA, Carlos Affonso et al. (coord.). Caderno especial: Lei Geral de Proteção de Dados (LGPD). São Paulo: Revista dos Tribunais, 2019, p. 175-176.

${ }^{36}$ Essa é a lição de FLUMIGNAN, Silvano José Gomes; FLUMIGNAN, Wévertton Gabriel Gomes. Princípios que regem o tratamento de dados no Brasil. In: LIMA, Cíntia Rosa Pereira de (coord.). Comentários à lei geral de proteção de dados. São Paulo: Almedina, 2020, p. 138.
} 
indagação: “de que adianta 'prestar contas', se, ao final, se houver incidente, por mais diligente que tenha sido, ele será responsabilizado da mesma forma e independentemente de culpa?"37 Assim, considerando-se que a prestação de contas, geralmente, está associada ao regime da responsabilidade subjetiva, o art. $6^{\circ}$, inciso $X$, da LGPD se mostra como mais um fundamento a favor da adoção da responsabilidade civil subjetiva pela LGPD.

\section{d) a previsão do art. 43, II, da LGPD;}

Como será analisado oportunamente, os defensores da responsabilidade civil objetiva, em geral, têm como base argumentativa analogias com o Código de Defesa do Consumidor. É inegável que algumas disposições da LGPD são in spiradas no CDC. Todavia, é importante ressaltar que o CDC possui previsão expressa acerca da natureza objetiva da responsabilidade, ${ }^{38}$ ao passo que a LGPD não.

Outro argumento capaz de fundamentar a analogia feita entre a LGPD e o CDC, pela corrente objetivista, é a "assimetria informacional entre os titulares dos dados e os agentes de tratamento" ${ }^{\prime 3}$. Em face desses argumentos, a corrente subjetivista enfatiza que ao contrário dos incisos I e III do art. 43, que nitidamente se referem à relação de causalidade, o art. 43, inciso $\mathrm{II}^{40}$, remeteria à ideia de culpa como fundamento da responsabilidade civil e sua redação é diferente da empregada pelo legislador no art. $12, \S 3^{\circ}$, do CDC. ${ }^{41}$ Nas palavras de Gisela Sampaio, trata-se da "pista mais importante que indica o regime adotado pela LGPD em matéria

\footnotetext{
${ }^{37}$ GUEDES, Gisela Sampaio da Cruz. Regime de responsabilidade adotado pela lei de proteção de dados brasileira. In: SOUZA, Carlos Affonso et al. (coord.). Caderno especial: Lei Geral de Proteção de Dados (LGPD). São Paulo: Revista dos Tribunais, 2019, p. 177.

${ }^{38}$ A título exemplificativo, confira-se a redação do art. 12 do CDC: "Art. 12. O fabricante, o produtor, o construtor, nacional ou estrangeiro, e o importador respondem, independentemente da existência de culpa, pela reparação dos danos causados aos consumidores por defeitos decorrentes de projeto, fabricação, construção, montagem, fórmulas, manipulação, apresentação ou acondicionamento de seus produtos, bem como por informações insuficientes ou inadequadas sobre sua utilização e riscos."

${ }^{39}$ GUEDES, Gisela Sampaio da Cruz. Regime de responsabilidade adotado pela lei de proteção de dados brasileira. In: SOUZA, Carlos Affonso et al. (coord.). Caderno especial LGPD. São Paulo: Revista dos Tribunais, 2019, p. 171.

40 “Art. 43. Os agentes de tratamento só não serão responsabilizados quando provarem: (...) II - que, embora tenham realizado o tratamento de dados pessoais que lhes é atribuído, não houve violação à legislação de proteção de dados;"

41 "Art. 12. O fabricante, o produtor, o construtor, nacional ou estrangeiro, e o importador respondem, independentemente da existência de culpa, pela reparação dos danos causados aos consumidores por defeitos decorrentes de projeto, fabricação, construção, montagem, fórmulas, manipulação, apresentação ou acondicionamento de seus produtos, bem como por informações insuficientes ou inadequadas sobre sua utilização e riscos. (...) $\S 3^{\circ} \mathrm{O}$ fabricante, o construtor, o produtor ou importador só não será responsabilizado quando provar: I - que não colocou o produto no mercado; II - que, embora haja colocado o produto no mercado, o defeito inexiste; III - a culpa exclusiva do consumidor ou de terceiro."
} 
de responsabilidade civil pelo tratamento de dados pessoais". E a autora completa: "se ele [agente de dados pessoais] conseguir provar que cumpriu todos os deveres impostos pela LGPD (...) não será responsabilizado." ${ }^{42}$

\section{e) redação com conotação negativa: adoção de um sistema de culpa presumida;}

Ainda nesse cenário, afirma-se também que o uso de redação com conotação negativa presente no caput do art. 43 da LGPD indica a adoção de um sistema de culpa presumida. ${ }^{43} \mathrm{O}$ dispositivo, ao tratar dos agentes de tratamento, utiliza a expressão "só não serão responsabilizados". Com base nisso, a doutrina subjetivista realiza analogia com os sistemas normativos da Itália e de Portugal, os quais adotaram previsão de culpa presumida por meio de uma redação bem semelhante à empregada no caput do art. 43 da LGPD.

É importante ressaltar que não há consenso na doutrina quanto à interpretação desses artigos atinentes ao Código Civil italiano e ao Código Civil português. Anderson Schreiber, por exemplo, assim como Gisela Sampaio, entende que são sim a caracterização de culpa presumida. ${ }^{44}$ No entanto, há autores que entendem que, na verdade, esses dispositivos seriam a concretização da previsão de uma responsabilidade civil objetiva. ${ }^{45}$

\footnotetext{
${ }^{42}$ GUEDES, Gisela Sampaio da Cruz. Regime de responsabilidade adotado pela lei de proteção de dados brasileira. In: SOUZA, Carlos Affonso et al. (coord.). Caderno especial: Lei Geral de Proteção de Dados (LGPD). São Paulo: Revista dos Tribunais, 2019, p. 179.

${ }^{43}$ Nesse sentido, é a lição de Gustavo Tepedino, Aline Terra e Gisela Sampaio: "A redação com conotação negativa ('só não será responsável quando'), empregada pelo legislador no caput do art. 43 da LGPD, sugere a adoção de um sistema de culpa presumida. No art. 493, '2', do Código Civil português, e no art. 2.050 do Código Civil italiano, o legislador também se valeu de uma redação que parte de uma presunção de culpa. (...) Tanto no sistema português quanto no italiano, se o agente conseguir demonstrar que 'empregou todas as providências exigidas' (redação do Código português) ou adotou 'todas as medidas idôneas a evitar o dano' (redação do Código italiano), ele se exime do dever de indenizar. Afirma-se, por isso mesmo, que não há nesses sistemas uma cláusula geral de risco (cláusula geral de responsabilidade objetiva), mas apenas um sistema intermediário de presunção de culpa. Presume-se a culpa do agente, mas esta pode ser afastada se ele conseguir demonstrar que observou o standard de conduta esperado, empregando medidas idôneas para evitar o dano. A presunção é, portanto, relativa. $\mathrm{O}$ art. 43 da LGPD seguiu exatamente esse caminho, preferindo estabelecer um sistema de presunção de culpa, do que adotar o modelo objetivo de responsabilidade e, nesse aspecto, afasta-se completamente do Código de Defesa do Consumidor" (TEPEDINO, Gustavo; TERRA, Aline de Miranda Valverde; GUEDES, Gisela Sampaio da Cruz. Fundamentos do direito civil: responsabilidade civil. Rio de Janeiro: Forense, 2020. v.4. E-book).

${ }^{44} \mathrm{Na}$ doutrina brasileira, ao tratar do art. 927, parágrafo único do Código Civil brasileiro, Anderson Schreiber também interpreta o art. 493, 2, do Código Civil português e o art. 2.050 do Código Civil italiano como manifestações expressas de culpa presumida. Confira-se: "Foi, contudo, mais além a nova codificação brasileira, ao optar francamente pela responsabilidade objetiva, e não por um sistema intermediário, de presunção de culpa, como fizeram os legisladores português e italiano" (SCHREIBER, Anderson. Novos paradigmas da responsabilidade civil: da erosão dos filtros da reparação à diluição dos danos. 6. ed. São Paulo: Atlas, 2015, p. 22).

${ }^{45}$ Nesse sentido, especificamente quanto à legislação italiana, manifestam-se Tarcisio Teixeira e Ruth Maria Guerreiro da Fonseca Armelin: "Comparativamente, o Código Civil italiano trata da responsabilidade objetiva no seu art. 2.050 ao prever que, aquele que causar dano a outrem pelo desenvolvimento de atividade perigosa, por sua
} 


\section{f) a previsão do art. 45 da LGPD;}

O art. 45 da LGPD estabelece que "[a]s hipóteses de violação do direito do titular no âmbito das relações de consumo permanecem sujeitas às regras de responsabilidade previstas na legislação pertinente." Com base nisso, defende-se que tal previsão caracteriza o argumento "definitivo" para fundamentar a adoção de um regime de responsabilidade civil pela LGPD distinto do disposto pelo CDC. Dito de outra forma, considerando que a LGPD enfatiza que se aplica o CDC nas hipóteses em que o titular dos dados for consumidor, o que a lei fez foi indicar que o regime de responsabilidade civil adotado na LGPD não é o da responsabilidade civil objetiva. $^{46}$

\section{g) do risco da criação de microssistemas;}

Também em prol do regime da responsabilidade civil subjetiva na LGPD, argumenta-se a existência de risco de criação de microssistemas se houvesse a ausência de necessidade da análise da culpa. Sob essa perspectiva, Carlos Nelson Konder e Marco Lima pontuam que "a prescindibilidade da análise de culpa no âmbito dos casos submetidos ao regime de responsabilidade da LGPD representaria a transformação da referida lei em um verdadeiro microssistema, com regras apartadas da lógica do restante do ordenamento jurídico."

\footnotetext{
natureza ou pela natureza dos meios empregados, é obrigado a indenizar; salvo se provar ter adotado todas as medidas idôneas para evitar o dano. Essa parte final figura como uma excludente de responsabilidade que não se vislumbra em nosso ordenamento jurídico" (TEIXEIRA, Tarcisio; ARMELIN, Ruth Maria Guerreiro da Fonseca. In: LIMA, Cíntia Rosa Pereira de. Comentários à lei geral de proteção de dados. São Paulo: Almedina, 2020, p. 308).

${ }^{46}$ Nesse sentido: "O argumento que parece ser definitivo, nesse ponto, é a previsão do art. 45 da referida lei (...). Nota-se, portanto, que a própria LGPD indica a adoção de um regime de responsabilidade diferente daquele adotado pelo CDC. Com efeito, a Lei de Proteção de Dados possibilita, expressamente, a aplicação do regime previsto no diploma consumerista quando o ofensor também for qualificado como fornecedor de produtos ou serviços no mercado de consumo. Em outras palavras, de acordo com a própria LGPD, aplica-se ao tratamento de dados no âmbito de uma relação de consumo o regime de responsabilidade objetiva, conforme previsto no CDC, indicando que o regime da Lei de Proteção de Dados seria outro" (KONDER, Carlos Nelson; LIMA, Marco Antônio de Almeida. Responsabilidade civil dos advogados no tratamento de dados à luz da Lei no 13.709/2018. In: EHRHARDT JÚNIOR, Marcos et al. (coord.). Direito civil e tecnologia. Belo Horizonte: Fórum, 2020, p. 423 424).
} 


\section{h) do possível desestímulo ao desenvolvimento de novas tecnologias e da necessidade de} segurança jurídica.

Outro argumento identificado em favor da responsabilidade civil subjetiva é no sentido de que a adoção do regime da responsabilidade civil objetiva ampliaria o número de demandas com viés ressarcitório, de modo a inibir o desenvolvimento de novas tecnologias de tratamento de dados no Brasil. ${ }^{47}$ Contra esse posicionamento, manifesta-se Maria Celina Bodin de Moraes, isso porque "a história já demonstrou que a adoção dos modelos de culpa presumida ou de responsabilidade objetiva, que flexibilizaram a dificuldade da prova da culpa, não limitaram o desenvolvimento de novas tecnologias."48-49

Por fim, à luz de um contexto de vazamento de dados, afirma-se a necessidade de se afastar a incidência automática da responsabilidade civil objetiva, uma vez que o escopo da LGPD seria o de garantir maior segurança aos titulares dos dados pessoais. Sendo assim, a adoção do regime de responsabilidade civil objetiva poderia implicar "insegurança jurídica profunda." ${ }^{50}$

\footnotetext{
${ }^{47}$ Confira-se: "A preocupação com a 'justa medida' permeia, na verdade, as discussões recentes sobre a responsabilidade civil mesmo na sua modalidade subjetiva, diante do reconhecimento de que um agravamento injustificado do dever de indenizar pode levar a sérios problemas econômicos, desestimulando o investimento empresarial e a assunção de riscos considerados desejáveis" (FRAZÃO, Ana. Risco da empresa e caso fortuito externo. In: Civilistica.com. 2016, a. 5, n. 1, p. 13. Disponível em: <http://civilistica.com/wpcontent/uploads1/2016/07/Fraz\%C3\%A3o-civilistica.com-a.5.n.1.2016-3.pdf>. Acesso em: 25 out. 2020).

${ }^{48}$ BODIN DE MORAES, Maria Celina. LGPD: um novo regime de responsabilização civil dito "proativo". Editorial à Civilistica.com, Rio de Janeiro, ano 8, n. 3, 2019, p. 4. Disponível em: <http://civilistica.com/lgpd-umnovo-regime/>. Acesso em: 25 out. 2020.

${ }^{49}$ Veja-se também pertinente lição de Stefano Rodotà: “Logo, não se pode julgar decisivo o argumento do aumento dos custos para as empresas (e para a administração pública) ocasionado pelas normas sobre a proteção de dados. As empresas já suportam custos por conta da tutela de interesses gerais, relacionados à segurança dos trabalhadores, tutela dos consumidores ou integridade do meio ambiente. Não se pode efetivamente estimar que os interesses ligados à proteção de dados sejam de ordem inferior. Além disso, não estamos diante de custos sociais decorrentes de simples problemas de internacionalização ou exteriorização, isto é, referentes considerações de mera oportunidade política ou de um mais vantajoso cálculo econômico. Trata-se, ao contrário, de impedir que tais efeitos, avaliados em linha de princípio como negativos, possam se produzir: e a única forma de impedir que isto aconteça consiste justamente em estabelecer determinadas obrigações a cargo dos coletores de informações" (RODOTÀ, Stefano. A vida na sociedade da vigilância: a privacidade hoje. Maria Celina Bodin de Moraes (Org.). Tradução: Danilo Doneda e Luciana Cabral Doneda. Rio de Janeiro: Renovar, 2008, p. 53).

${ }^{50}$ Nesse sentido, confira-se: "Diante disso, com a necessidade de prova técnica sobre o vazamento de dados e suas causas, a boa exegese legal deverá afastar o automatismo da responsabilização objetiva pura, nesse caso. Pois, como visto no exemplo hipotético acima, a verificação da conduta ilícita imporá conhecimento técnico específico. Sem isso, a diligência pode ser mal compreendida, gerando insegurança jurídica profunda. $\mathrm{O}$ anseio da lei é buscar mais segurança aos usuários, mas isso tem de ser balanceado com a realidade do mundo digital. Espera-se, desta feita, que esse tipo de questão seja tratada cum grano salis. Caso contrário, a lei criará uma situação de profunda injustiça" (CORRÊA, Leonardo. É importante não perder o foco da segurança jurídica no âmbito da LGPD. In: Conjur. Disponível em: <https://www.conjur.com.br/2019-mar-03/leonardo-correa-seguranca-juridica-ambitolgpd >. Acesso em: 25 out. 2020.)
} 


\subsection{Regime da responsabilidade civil objetiva}

Como adiantado, há verdadeira cisão, na doutrina, entre dois principais entendimentos acerca do regime da responsabilidade civil eleito pela LGPD. Vistos os principais argumentos levantados pela corrente que advoga pela responsabilidade subjetiva, passa-se à análise das premissas e fundamentos suscitados por aqueles que, na contramão, entendem que o regime pretendido pelo legislador foi, na realidade, o da responsabilidade civil objetiva.

Segundo essa segunda corrente, a intenção do legislador teria sido a de responsabilizar os agentes pelos danos causados a partir do tratamento de dados independentemente da demonstração de culpa. Dito diversamente, a simples configuração do dano seria suficiente para gerar o dever de indenizar, sem qualquer necessidade de se aferir, no caso concreto, se houve ou não descumprimento de algum dos deveres específicos impostos pela LGPD aos agentes de tratamento de dados.

\section{a) programa principiológico estabelecido pela LGPD;}

Em primeiro lugar, aqueles que integram a corrente objetivista defendem a necessidade de se fazer uma avaliação dos fundamentos principiológicos da LGPD, já que seriam tais princípios verdadeiras "bússolas", aptas a indicar a mens legis e verdadeira intenção do legislador. Assim, para a adequada compreensão dos conceitos e normas cuja extensão ficaram em aberto (como é o caso do regime de responsabilidade civil imposto aos agentes de tratamento de dados), seria essencial uma leitura sistemática da lei.

Seguindo essa linha de raciocínio e considerando que o legislador se preocupou em enumerar uma série de princípios para fundamentar direitos, sanções e regulamentações específicas sobre a proteção de dados, estes deveriam servir como norte para a interpretação dos demais dispositivos legais. Em outras palavras, dever-se-ia aproveitar o conteúdo desses princípios para a extração do "DNA" da lei. Assim, a investigação pautada nesse arcabouço principiológico representaria o caminho ideal para se aferir se o objetivo da lei, em última instância, foi o de conferir uma proteção irrestrita aos titulares dos dados (pautada na responsabilidade civil objetiva) ou se meramente subjetiva, vinculada à demonstração de culpa por parte dos agentes de tratamento.

Portanto, antes de qualquer outro argumento, a doutrina destaca a importância de 
se "fazer uma digressão para analisar o programa principiológico trazido pela LGPD" 51 , haja vista que é o conteúdo de alguns princípios que indicará o caráter objetivo no regime de responsabilização estipulado por referido diploma legal.

Nesse contexto, Danilo Doneda e Laura Mendes destacam o que estava por trás da preocupação do legislador em enumerar uma série de princípios na própria letra da lei: trata-se de "um recurso que considerou a novidade da matéria e a necessidade de estabelecer as principais balizas para os seus princípios fundamentais, tanto por uma questão de uniformidade e, até mesmo, didática, e que considerou a fortíssima carga que está por trás de diversos desses princípios apresentados na Lei" ${ }^{\circ 5}$.

Ainda sob o ponto de vista principiológico, destaca-se que a estrutura da LGPD se assemelha, em muito, à do Código de Defesa do Consumidor e à do Marco Civil da Internet, haja vista que todos os três diplomas legais possuem estrutura principiológica que fundamenta os demais direitos, deveres e regulamentações, de modo que as demais regras decorrem diretamente dos princípios que são inicialmente estabelecidos. Como se verá melhor a frente, essa similitude entre os três diplomas legais também ocupa papel de protagonismo na argumentação doutrinária destinada a demonstrar que o regime eleito pela LGPD foi o da responsabilidade civil objetiva dos agentes de tratamento de dados.

Analisando-se especificamente o teor de alguns dos princípios elencados na LGPD, Caitlin Mulholland destaca três deles que seriam "os princípios fundantes da responsabilidade civil por risco" ${ }^{53}$, quais sejam: o princípio da segurança; da prevenção; e, por fim, da responsabilização e prestação de contas (previstos, respectivamente, nos incisos VII, VIII e X do art. $6^{\circ}$ da LGPD). Com efeito, referidos princípios e suas respectivas definições trariam, em sua essência, uma verdadeira fundamentação que permitiria ao intérprete considerar que a LGPD é, de fato, uma lei que protege ao titular de dados e concede a ele um direito a ser indenizado com base na teoria do risco.

Nesse contexto, a interpretação sistemática - pautada nos princípios listados pela lei - seria capaz, por si só, de denotar que o regime eleito foi o da responsabilidade objetiva. Nesse sentido, afirma-se que uma interpretação sistemática e principiológica da LGPD não

\footnotetext{
${ }^{51}$ MENDES, Laura Schertel; DONEDA, Danilo. Reflexões iniciais sobre a nova lei geral de proteção de dados. Revista de Direito do Consumidor, São Paulo, v. 27, n. 120, p. 469-483, nov./dez. 2018, p. 470.

${ }^{52}$ MENDES, Laura Schertel; DONEDA, Danilo. Reflexões iniciais sobre a nova lei geral de proteção de dados. Revista de Direito do Consumidor, São Paulo, v. 27, n. 120, p. 469-483, nov./dez. 2018, p. 471.

${ }^{53}$ MULHOLLAND, Caitlin. A LGPD e o fundamento da responsabilidade civil dos agentes de tratamento de dados pessoais: culpa ou risco? Migalhas, 2020. Disponível em: <https://migalhas.uol.com.br/coluna/migalhasde-responsabilidade-civil/329909/a-lgpd-e-o-fundamento-da-responsabilidade-civil-dos-agentes-detr\%E2\%80\%A6>. Acesso em: 10 fev. 2021.
} 
deixaria dúvidas de que o regime que efetivamente se pretendeu adotar é o da responsabilização independentemente da aferição de culpa. Essa conclusão, por evidente, não se pauta exclusivamente na análise dos princípios e da interpretação sistemática, mas, segundo essa corrente doutrinária, tais elementos já seriam suficientes para "dar o tom” do que se esperar em termos de tratamento de dados e a correspondente responsabilização em caso de danos.

\section{b) interpretação dos artigos 42 e 44 da LGPD: riscos inerentes à atividade de tratamento de dados;}

Além da interpretação sistemática pautada nos princípios elencados pela LGPD, os adeptos da corrente objetivista também se apoiam na análise específica dos artigos 42 e 44 da LGPD, tidos como verdadeiro núcleo da divergência doutrinária ora analisada, para reforçar sua tese. Nas conflitantes interpretações feitas de tais dispositivos, faz-se verdadeiro exercício voltado a tentar identificar o que pretendeu o legislador ao estabelecer o dever de reparar os danos oriundos do tratamento de dados, sem, contudo, ter deixado claro o tipo de responsabilização (isto é, sem qualquer menção ao risco, tampouco à culpa).

Em que pese a aparente contradição entre o caput do art. 42 e o parágrafo único do art. 44, haja vista que o primeiro impõe a obrigação de indenizar "em razão do exercício de atividade de tratamento de dados pessoais", enquanto o segundo determina a obrigação de indenizar caso haja tratamento irregular de dados pessoais, identificado como aquele decorrente da "violação da segurança dos dados" por se "deixar de adotar as medidas de segurança", Caitlin Mulholland defende que o legislador quis, no segundo dispositivo, "identificar nessa hipótese situações danosas que decorrem especificamente de incidentes de segurança que são, por sua vez, acontecimentos que se relacionam ao risco inerente ao desenvolvimento da atividade de tratamento de dados, como vazamentos não intencionais e invasão de sistemas e bases de dados por terceiros não autorizados" ${ }^{24}$.

Com efeito, afirma-se que tais riscos "deveriam ser necessariamente situados como intrínsecos à atividade de tratamento de dados e, portanto, considerados, em última análise, como hipótese de fortuito interno, incapazes de afastar a obrigação dos agentes de tratamento

\footnotetext{
${ }^{54}$ MULHOLLAND, Caitlin. A LGPD e o fundamento da responsabilidade civil dos agentes de tratamento de dados pessoais: culpa ou risco? Migalhas, 2020. Disponível em: <https://migalhas.uol.com.br/coluna/migalhasde-responsabilidade-civil/329909/a-lgpd-e-o-fundamento-da-responsabilidade-civil-dos-agentes-detr\%E2\%80\%A6>. Acesso em: 10 fev. 2021.
} 
de reparar os danos causados pelos incidentes" ${ }^{\prime 55}$.

O que essa parcela da doutrina conclui, portanto, é que apesar do uso de expressões diversas em sua redação, tanto o artigo 42, quanto o artigo 44 da LGPD indicam a estipulação do regime da responsabilidade civil objetiva, impondo aos agentes de tratamento a obrigação de indenizar os danos causados aos titulares de dados, independentemente da existência de conduta culposa por parte do controlador ou operador ${ }^{56}$. Isso porque, quando o artigo 44 se refere à atividade irregularmente realizada no tratamento de dados, ela é irregular por não atender a um nível mínimo de segurança que é esperado nesse tipo de tratamento, e é justamente essa falha na segurança que consiste em risco intrínseco ao tratamento.

Ainda sobre esse ponto, é travada relevante discussão ao redor da seguinte questão: as atividades de tratamento de dados são atividades de risco? Dito diversamente, trata-se de uma atividade que representa um risco a priori em todas as suas modalidades?

Para Danilo Doneda e Laura Mendes, a atividade de tratamento de dados "encerra um risco intrínseco, na medida em que há uma potencialidade danosa considerável em caso de violação desses direitos, que se caracterizam por sua natureza de direito personalíssimo e de direito fundamental" ${ }^{57}$. São precisamente as considerações a respeito da finalidade da lei e dos princípios por ela eleitos (principalmente os da necessidade, minimização, responsabilização e prestação de contas), que levam os autores a, em última instância, vincular o exercício da atividade de tratamento de dados pessoais a um risco inerente, potencialmente causador de danos a seus titulares.

Tal conclusão é fundamentada, portanto, pelo fato de a atividade desenvolvida pelo agente de tratamento ser uma atividade que impõe riscos aos direitos dos titulares de dados, que, por sua vez, são intrínsecos, inerentes à própria atividade. Há, ainda, quem argumente que tais danos, por serem quantitativamente elevados e qualitativamente graves, "atingiriam direitos difusos, o que, por si só, justificaria a adoção do regime da responsabilidade civil objetiva, tal como no caso dos danos ambientais e dos danos causados por acidentes de consumo"58.

\footnotetext{
${ }^{55}$ MULHOLLAND, Caitlin. A LGPD e o fundamento da responsabilidade civil dos agentes de tratamento de dados pessoais: culpa ou risco? Migalhas, 2020. Disponível em: <https://migalhas.uol.com.br/coluna/migalhasde-responsabilidade-civil/329909/a-lgpd-e-o-fundamento-da-responsabilidade-civil-dos-agentes-detr\%E2\%80\%A6>. Acesso em: 10 fev. 2021.

${ }^{56}$ MULHOLLAND, Caitlin. A LGPD e o fundamento da responsabilidade civil dos agentes de tratamento de dados pessoais: culpa ou risco? Migalhas, 2020. Disponível em: <https://migalhas.uol.com.br/coluna/migalhasde-responsabilidade-civil/329909/a-lgpd-e-o-fundamento-da-responsabilidade-civil-dos-agentes-detr\%E2\%80\%A6>. Acesso em: 10 fev. 2021.

${ }^{57}$ MENDES, Laura Schertel; DONEDA, Danilo. Reflexões iniciais sobre a nova lei geral de proteção de dados. Revista de Direito do Consumidor, São Paulo, v. 27, n. 120, p. 469-483, nov./dez. 2018.

${ }^{58}$ MULHOLLAND, Caitlin. A LGPD e o fundamento da responsabilidade civil dos agentes de tratamento de dados pessoais: culpa ou risco? Migalhas, 2020. Disponível em: <https://migalhas.uol.com.br/coluna/migalhas-
} 
Ademais, a corrente objetivista destaca que a legislação de proteção de dados tem como um dos seus principais fundamentos a diminuição de riscos de dano. Tanto assim é que a lei adota, no inciso III do artigo $6^{\circ}$, o princípio da necessidade, que impõe a "limitação do tratamento ao mínimo necessário para a realização de suas finalidades, com abrangência dos dados pertinentes, proporcionais e não excessivos em relação às finalidades do tratamento de dados". Tal princípio, ao lado de outros com a mesma ratio - como os princípios da minimização, responsabilidade e prestação de contas, entre outros - evidenciam a finalidade da lei e levam à conclusão de que o legislador optou por um regime de responsabilidade objetiva, vinculando o exercício da atividade de tratamento de dados pessoais a um risco inerente, potencialmente causador de danos a seus titulares ${ }^{59}$.

Para corroborar esse entendimento, destaca-se o dever imposto pela lei de apresentar um relatório de impacto à proteção de dados pessoais (previsto no art. $5^{\circ}, \mathrm{XVII}^{60}, \mathrm{e}$ no art. $10, \S 3^{\circ}$, da $\operatorname{LGPD}^{61}$ ). Tal previsão legislativa também denotaria o caráter de atividade de risco inerente ao tratamento de dados, haja vista que esse relatório - e, principalmente, o fato de poder ser exigido pela autoridade nacional de proteção de dados ainda que não haja prova ou indícios de violações - deixa clara a potencialidade lesiva da atividade, daí ser imprescindível a existência desse dever constante de informar quais os riscos a que determinado tratamento de dados está sujeito, bem como descrever todo o procedimento de tratamento de dados, a metodologia da coleta e indicar as medidas e mecanismos adotados para mitigar esses riscos.

Em suma, o que se sustenta é que o escopo da LGPD foi limitar o tratamento dos dados para diminuir o risco de vazamentos, e por que isso foi pretendido? Porque o próprio tratamento de dados, em si, apresenta risco intrínseco aos seus titulares, daí decorrendo a necessidade de se estipular um regime objetivo de responsabilidade civil.

\footnotetext{
de-responsabilidade-civil/329909/a-lgpd-e-o-fundamento-da-responsabilidade-civil-dos-agentes-detr\%E2\%80\%A6>. Acesso em: 10 fev. 2021.

${ }^{59}$ MENDES, Laura Schertel; DONEDA, Danilo. Reflexões iniciais sobre a nova lei geral de proteção de dados. Revista de Direito do Consumidor, São Paulo, v. 27, n. 120, p. 469-483, nov./dez. 2018, p. 475.

${ }^{60}$ Art. $5^{\circ}$ Para os fins desta Lei, considera-se:

(...)

XVII - relatório de impacto à proteção de dados pessoais: documentação do controlador que contém a descrição dos processos de tratamento de dados pessoais que podem gerar riscos às liberdades civis e aos direitos fundamentais, bem como medidas, salvaguardas e mecanismos de mitigação de risco;

61 “Art. 10. O legítimo interesse do controlador somente poderá fundamentar tratamento de dados pessoais para finalidades legítimas, consideradas a partir de situações concretas, que incluem, mas não se limitam a:

(...)

$\S 3^{\circ} \mathrm{A}$ autoridade nacional poderá solicitar ao controlador relatório de impacto à proteção de dados pessoais, quando o tratamento tiver como fundamento seu interesse legítimo, observados os segredos comercial e industrial".
} 


\section{c) a previsão do art. 43 da LGPD;}

Ao lado dos argumentos já expostos, destaca-se a redação do artigo 43 da LGPD. O legislador, ao utilizar-se da expressão "só não respondem", acabou por delimitar as únicas hipóteses em que o agente de tratamento não será responsabilizado, quais sejam: (i) se não realizou o tratamento que é a ele imputado; (ii) se, embora tenha realizado, não houve violação à legislação de proteção de dados; e, por fim, (iii) se o dano decorrer de atividade exclusiva do titular de dados ou de terceiros. De forma residual, conclui-se que, em não se tratando de uma das três hipóteses, o agente de tratamento responde independentemente de culpa.

Procedendo-se à comparação com o código consumerista, conclui-se que a estrutura do dispositivo e a redação dessas excludentes se aproximam, em muito, ao que estipula o art. $12, \S 3^{\circ}$, do CDC, e é precisamente essa similitude (tanto estrutural, quanto em termos de conteúdo) que parece indicar a natureza jurídica da responsabilidade objetiva da LGPD, haja vista que, se assim não fosse, não existiria a necessidade de se estipular esse rol exclusivo e taxativo das excludentes - bastaria demonstrar que não houve culpa. Assim, a partir do momento em que legislador traz referido rol taxativo, o sistema da LGPD parece ser o da responsabilização objetiva com uma restrição quanto às excludentes ${ }^{62}$. Isso porque, não haveria motivo para o legislador ter seguido os mesmos moldes do CDC se sua intenção, ao final, não era a de estipular um regime que se aproximasse das relações consumeristas (tradicionalmente caracterizadas pela responsabilidade de natureza objetiva).

\section{d) similitude entre a LGPD e o CDC;}

Nesse contexto, passa-se à análise de mais um recorrente argumento invocado pela parcela da doutrina que defende a existência de um regime de responsabilidade objetiva: a similitude da LGPD com o CDC e com o Marco Civil da Internet. A doutrina, ao refletir sobre as principais influências que moldaram a LGPD, verifica que ela se inspira, em primeiro lugar, no modelo europeu de proteção de dados, mas também é facilmente identificada uma influência

\footnotetext{
${ }^{62}$ MULHOLLAND, Caitlin. A LGPD e o fundamento da responsabilidade civil dos agentes de tratamento de dados pessoais: culpa ou risco? Migalhas, 2020. Disponível em: <https://migalhas.uol.com.br/coluna/migalhasde-responsabilidade-civil/329909/a-lgpd-e-o-fundamento-da-responsabilidade-civil-dos-agentes-detr\%E2\%80\%A6>. Acesso em: 10 fev. 2021.
} 
da legislação brasileira, especialmente do $\mathrm{CDC}^{63}$. Nesse contexto, as semelhanças entre os dois diplomas consistem em mais um fundamento levantado pela doutrina para defender a eleição de um regime objetivo de responsabilização.

Em primeiro lugar, verifica-se que a própria lógica da atividade de tratamento de dados parte da ideia de vulnerabilidade do indivíduo lesado (aí incluído não apenas o titular dos dados, mas também eventuais terceiros afetados pelo vazamento de dados ${ }^{64}$ ), que seria análoga à vulnerabilidade do consumidor. Por conseguinte, a doutrina se apoia na ideia de que o indivíduo lesado ocuparia uma posição de vulnerabilidade em face dos controladores e operadores, "que costuma se manifestar tanto em ordem técnica quanto econômica", e é justamente essa vulnerabilidade que acabaria "por realizar uma aproximação do regime de responsabilidade na LGPD àquele disposto pelo CDC" 65 .

Nessa direção, "tal proximidade parece muitas vezes corroborada pela própria LGPD" ${ }^{66}$, como se depreende da leitura do seu art. $2^{\circ}$, VI, que estipula como um dos fundamentos da proteção de dados pessoais, justamente, a defesa dos direitos do consumidor. Além disso, ao prever os direitos dos titulares de dados, o $§ 8^{\circ}$ do art. 18 da LGPD estabelece que "o titular teria o direito de peticionar em relação aos seus dados não somente perante a Autoridade Nacional de Proteção de Dados (ANPD), mas também a organismos de defesa do consumidor"67.

Ademais, a similitude estrutural entre a LGPD e o CDC evidenciaria a intenção do legislador principalmente quando comparados os já mencionados artigos de excludente de responsabilidade da LGPD com aqueles do CDC (isto é, o art. 43 da LGPD e os arts. 12, §3º $14, \S 3^{\circ}$, do CDC), que denotam que as excludentes de responsabilidade civil da LGPD seguiram

\footnotetext{
${ }^{63}$ MENDES, Laura Schertel; DONEDA, Danilo. Reflexões iniciais sobre a nova lei geral de proteção de dados. Revista de Direito do Consumidor, São Paulo, v. 27, n. 120, p. 469-483, nov./dez. 2018, p. 473.

${ }^{64}$ Importante destacar a ressalva feita por Carlos Nelson Konder e Marco Antonio Lima, no sentido de que "a LGPD não limita a vítima da ofensa à figura do titular dos dados", estendendo o conceito de "lesado" a todas as possíveis vítimas daquela violação. Assim, quando o art. 42 usa o termo "causar dano a outrem" e não "ao titular dos dados", ela acertou, o que se aplicaria em caso, por exemplo, de vazamento de dados genéticos, que podem gerar danos a pessoas mantenham grau de parentesco próximo. (KONDER, Carlos Nelson; LIMA, Marco Antônio de Almeida. Responsabilidade civil dos advogados no tratamento de dados à luz da Lei $\mathrm{n}^{\circ}$ 13.709/2018. In: EHRHARDT JÚNIOR, Marcos et al. (coord.). Direito civil e tecnologia. Belo Horizonte: Fórum, 2020, p. 419420).

${ }^{65}$ KONDER, Carlos Nelson; LIMA, Marco Antônio de Almeida. Responsabilidade civil dos advogados no tratamento de dados à luz da Lei no 13.709/2018. In: EHRHARDT JÚNIOR, Marcos et al. (coord.). Direito civil e tecnologia. Belo Horizonte: Fórum, 2020, p. 420-421.

${ }^{66}$ KONDER, Carlos Nelson; LIMA, Marco Antônio de Almeida. Responsabilidade civil dos advogados no tratamento de dados à luz da Lei no 13.709/2018. In: EHRHARDT JÚNIOR, Marcos et al (coord.). Direito civil e tecnologia. Belo Horizonte: Fórum, 2020, p. 421.

${ }^{67}$ KONDER, Carlos Nelson; LIMA, Marco Antônio de Almeida. Responsabilidade civil dos advogados no tratamento de dados à luz da Lei no 13.709/2018. In: EHRHARDT JÚNIOR, Marcos et al. (coord.). Direito civil e tecnologia. Belo Horizonte: Fórum, 2020, p. 421.
} 
o padrão daquelas do CDC. O mesmo ocorre quando são comparados o art. 44 da LGPD e o art. $14, \S 1^{\circ}$, do CDC, "em que há uma aproximação significativa entre o tratamento irregular dos dados pessoais aos defeitos de serviço no mercado de consumo" $" 68$.

Ainda em termos de "inspiração", tem-se que a redação do art. 64 da LGPD também foi inspirada no art. $7^{\circ}$ do CDC, como ocorre com outras várias regras de responsabilidade, tais como (i) a possibilidade de danos coletivos, (ii) o conceito de tratamento impróprio de dados e (iii) a possibilidade de inversão do ônus da prova que a LGPD traz no $\S 2^{\circ}$ do art. 42 (que, inclusive, contém uma redação parecida com a do art. $6^{\circ}$, VIII, do CDC e que, inclusive, ostenta os mesmos requisitos do CDC, como a demonstração de verossimilhança e hipossuficiência do titular de $\left.\operatorname{dados}^{69}\right)$. É uma possibilidade, aliás, que está muito relacionada ao princípio da responsabilização e prestação de contas, que impõe aos controladores e operadores que demonstrem que adotaram todas as medidas estabelecidas em lei para evitar danos.

Nesse cenário, resta inegável que a LGPD se conecta ao código consumerista e que, em assim sendo, deve-se interpretar toda a legislação dentro de um ambiente que é integral, ou seja, o ordenamento deve ser lido e interpretado como um todo, sistematicamente, e não cada diploma legal de forma estanque e individualizada. Portanto, defende-se uma interpretação da LGPD que leve em consideração o Código Civil e o CDC naquilo que comumente se denomina diálogo das fontes legislativas ${ }^{70}$.

Dessa maneira, entende-se que, no ordenamento brasileiro, a proteção de dados sempre se encontrará intimamente ligada à defesa do consumidor. Logo, "em um pensamento objetivista, essa estreita ligação significaria uma vontade do legislador de, sempre que possível, transpor os instrumentos de defesa do consumidor para a proteção de dados pessoais"

\footnotetext{
${ }^{68}$ KONDER, Carlos Nelson; LIMA, Marco Antônio de Almeida. Responsabilidade civil dos advogados no tratamento de dados à luz da Lei no 13.709/2018. In: EHRHARDT JÚNIOR, Marcos et al (coord.). Direito civil e tecnologia. Belo Horizonte: Fórum, 2020, p. 421.

${ }^{69} \mathrm{LGPD}$, art. $42, \S 2^{\mathrm{o}}$. "O juiz, no processo civil, poderá inverter o ônus da prova a favor do titular dos dados quando, a seu juízo, for verossímil a alegação, houver hipossuficiência para fins de produção de prova ou quando a produção de prova pelo titular resultar-lhe excessivamente onerosa".

CDC, Art. $6^{\circ}$. "São direitos básicos do consumidor: (...) VIII - a facilitação da defesa de seus direitos, inclusive com a inversão do ônus da prova, a seu favor, no processo civil, quando, a critério do juiz, for verossímil a alegação ou quando for ele hipossuficiente, segundo as regras ordinárias de experiências".

${ }^{70}$ MENDES, Laura Schertel; DONEDA, Danilo. Reflexões iniciais sobre a nova lei geral de proteção de dados. Revista de Direito do Consumidor, São Paulo, v. 27, n. 120, p. 469-483, nov./dez. 2018, p. 473.

${ }^{71}$ KONDER, Carlos Nelson; LIMA, Marco Antônio de Almeida. Responsabilidade civil dos advogados no tratamento de dados à luz da Lei no 13.709/2018. In: EHRHARDT JÚNIOR, Marcos et al. (coord.). Direito civil e tecnologia. Belo Horizonte: Fórum, 2020, p. 422.
} 


\section{e) irrelevância das exclusões feitas durante a tramitação do projeto de lei;}

Como visto, um dos argumentos levantados pela corrente subjetivista diz respeito ao histórico de tramitação do projeto de lei que deu origem à LGPD, período em que algumas menções à responsabilidade objetiva foram suprimidas. Essa circunstância formal teria levado parte da doutrina a alegar que, caso o objetivo do legislador fosse o de estabelecer o regime de responsabilidade objetiva, não teria realizado tais alterações.

Para os defensores do regime objetivo de responsabilidade civil, tal argumento não seria relevante, afirmando-se que, se o legislador intentou desnudar a natureza da responsabilidade civil objetiva e transformá-la em subjetiva, não conseguiu. Como demonstrado, a lei não é clara nesse ponto (nem para um lado, nem para o outro), pelo que a única forma de se averiguar qual foi a real intenção do legislador seria através de uma interpretação sistemática e principiológica da lei. Seguindo essa linha de raciocínio e levando em consideração a forma com que a lei foi promulgada e que se encontra hoje em vigor, a única interpretação possível seria a de que o regime eleito foi o da responsabilidade objetiva.

Esse é o entendimento que a corrente objetivista extrai de uma leitura feita a partir do "todo" da lei geral de proteção de dados e da análise principiológica por ela trazida. Sustentase, para arrematar, que se a intenção era eleger o regime da responsabilidade civil subjetiva, o legislador deveria, necessariamente, ter alterado outros inúmeros dispositivos da lei que se tornariam incompatíveis com o regime de responsabilidade subjetiva. Como não o fez, não há outra interpretação possível senão a de que o regime eleito foi o da responsabilidade objetiva.

\section{f) criação de standards de conduta que não se confundem com culpa normativa.}

Por fim, de forma a rebater o argumento que é comumente in vocado pela corrente que defende o regime da responsabilidade subjetiva (exposto no item 4.1.a acima), baseado nos supostos standards de conduta a serem seguidos pelos agentes de tratamento - listados nos artigos 46 a 54 da LGPD, que tratam de deveres de segurança, sigilo, boas práticas, governança de dados, entre outros - a corrente objetivista sustenta, em contraposição, que o legislador em nenhum momento se referiu a deveres de conduta e, por isso, referidos dispositivos tratam apenas do "estabelecimento de regras de boas práticas e de governança, que possuem característica muito mais objetiva do que ligada a uma suposta culpa normativa"72. Em outras

\footnotetext{
${ }^{72}$ MULHOLLAND, Caitlin. A LGPD e o fundamento da responsabilidade civil dos agentes de tratamento de
} 
palavras, funcionam como meras diretrizes para o bom desenvolvimento da atividade voltado ao tratamento de dados e não como deveres de conduta aptos a limitar os casos de responsabilização dos agentes de tratamento.

Ainda sobre esse ponto, destaca-se outro relevante argumento: o Código de Defesa do Consumidor também criou diversos deveres de conduta e, não obstante, o regime escolhido foi o da responsabilidade civil objetiva. Vê-se, portanto, que uma coisa não está necessariamente atrelada a outra. Com efeito, o que está por trás desses ditos deveres de conduta é o objetivo da lei de não se limitar a reparar a vítima após a materialização do dano, mas, principalmente, prevenir a ocorrência do dano de forma a proteger os dados, e foi exatamente isso que se pretendeu no Capítulo VII da LGPD (“[d]a segurança e das boas práticas”) - que, por isso mesmo, está muito mais relacionado à prevenção dos danos do que à reparação dos danos.

Nesse sentido, Danilo Doneda e Laura Mendes destacam que “a LGPD se inspirou e em muitos pontos segue os padrões internacionais, que são leis que tem sempre uma regulamentação específica de boas práticas e medidas de segurança (como a GDPR etc)"73, tratando-se, pois, de prática comum no contexto europeu. Assim, o simples fato de ter "bebido na fonte" dessas normas internacionais e usado esse modelo de regulação não significa que a LGPD elegeu o sistema da responsabilidade civil subjetiva.

\section{Conclusão}

Como exposto, a divergência tratada no presente estudo está longe de atingir um consenso doutrinário e os argumentos levantados por ambas as correntes são relevantes e plausíveis em níveis equilibrados, daí podendo se concluir que a questão dificilmente será pacificada em momento próximo e, com efeito, demandará enfrentamento no âmbito jurisprudencial. Lá, provavelmente será alvo de decisões igualmente conflitantes, justamente porque o legislador deixou a cargo do intérprete definir qual é o regime de responsabilidade a ser aplicado aos agentes de tratamento de dados.

\footnotetext{
dados pessoais: culpa ou risco? Migalhas, 2020. Disponível em: <https://migalhas.uol.com.br/coluna/migalhasde-responsabilidade-civil/329909/a-lgpd-e-o-fundamento-da-responsabilidade-civil-dos-agentes-detr\%E2\%80\%A6>. Acesso em: 10 fev. 2021.

${ }^{73}$ MENDES, Laura Schertel; DONEDA, Danilo. Reflexões iniciais sobre a nova lei geral de proteção de dados. Revista de Direito do Consumidor, São Paulo, v. 27, n. 120, p. 469-483, nov./dez. 2018.
} 
Em que pese a controvérsia doutrinária, pondera-se que a solução não deverá estar, necessariamente, em um dos dois extremos: responsabilidade objetiva ou subjetiva para todo e qualquer caso. A doutrina vem se esforçando na tentativa de achar soluções intermediárias, como o caso da já mencionada teoria da responsabilidade civil "proativa" 74 e, por outro lado, até mesmo suscitando indagações sobre se o regime deveria variar de acordo com as peculiaridades do caso concreto. É o que sugerem, por exemplo, Gisela Guedes e Rose Meireles quando vislumbram a possibilidade de o regime ser objetivo nos casos específicos de tratamento de dados sensíveis ${ }^{75}$.

De fato, o modelo binário (“ou isso, ou aquilo") parece ser insuficiente para resolver questões de tamanha complexidade como a ora analisada e, possivelmente, foi tal aspecto que levou o legislador a deixar a questão em aberto, passível de diferentes interpretações. Nesse contexto, é inegável que uma análise casuística, ou seja, considerando as singularidades de cada caso concreto, poderia se revelar como uma possível e eficiente solução, rejeitando-se, assim, o enquadramento apriorístico para toda e qualquer situação fática que possa se apresentar.

\section{Referências}

BODIN DE MORAES, Maria Celina. LGPD: um novo regime de responsabilização civil dito "proativo". Editorial à Civilistica.com. Rio de Janeiro: a. 8, n. 3, 2019. Disponível em: <http://civilistica.com/lgpd-um-novo-regime/>. Acesso em: 25 out. 2020.

BODIN DE MORAES, Maria Celina. Risco, solidariedade e responsabilidade objetiva. In: Revista dos Tribunais. v. 854, pp. 11-37, dez./2006.

CAPANEMA, Walter Aranha. A responsabilidade civil na Lei Geral de Proteção de Dados. Cadernos Jurídicos, São Paulo, v. 21, n. 53, p. 163-170, jan./mar. 2020.

CORRÊA, Leonardo. É importante não perder o foco da segurança jurídica no âmbito da LGPD. In: Conjur. Disponível em: <https://www.conjur.com.br/2019-mar-03/leonardo-correaseguranca-juridica-ambito-lgpd>. Acesso em: 25 out. 2020.

FLUMIGNAN, Silvano José Gomes; FLUMIGNAN, Wévertton Gabriel Gomes. Princípios que regem o tratamento de dados no Brasil. In: LIMA, Cíntia Rosa Pereira de (coord.). Comentários à lei geral de proteção de dados. São Paulo: Almedina, 2020.

\footnotetext{
${ }^{74}$ BODIN DE MORAES, Maria Celina. LGPD: um novo regime de responsabilização civil dito "proativo". Civilistica.com, Rio de Janeiro, ano 8, n. 3, 2019. Disponível em: <http://civilistica.com/lgpd-um-novo-regime/>. Acesso em: 25 out. 2020.

${ }^{75}$ GUEDES, Gisela Sampaio da Cruz; MEIRELES, Rose Melo Vencelau. Término do tratamento de dados. In: TEPEDINO, Gustavo; FRAZÃO, Ana; OLIVA, Milena Donato (coord.). Lei Geral de Proteção de Dados Pessoais e suas repercussões no direito brasileiro. São Paulo: Thomson Reuters Brasil, 2019, p. 236.
} 
FRAZÃO, Ana. Risco da empresa e caso fortuito externo. In: Civilistica.com. 2016, a. 5, n.1. Disponível em: <http://civilistica.com/wp-content/uploads1/2016/07/Fraz\%C3\%A3ocivilistica.com-a.5.n.1.2016-3.pdf>. Acesso em: 25 out. 2020.

GUEDES, Gisela Sampaio da Cruz. Regime de responsabilidade adotado pela lei de proteção de dados brasileira. In: SOUZA, Carlos Affonso et al (coords.). Caderno especial: Lei Geral de Proteção de Dados (LGPD). São Paulo: Revista dos Tribunais, 2019.

GUEDES, Gisela Sampaio da Cruz; MEIRELES, Rose Melo Vencelau. Término do tratamento de dados. In: TEPEDINO, Gustavo; FRAZÃO, Ana; OLIVA, Milena Donato (coord.). Lei Geral de Proteção de Dados Pessoais e suas repercussões no direito brasileiro. São Paulo: Thomson Reuters Brasil, 2019, p. 236.

KONDER, Carlos Nelson; LIMA, Marco Antônio de Almeida. Responsabilidade civil dos advogados no tratamento de dados à luz da Lei $\mathrm{n}^{\circ}$ 13.709/2018. In: EHRHARDT JÚNIOR, Marcos et al (coords.). Direito civil e tecnologia. Belo Horizonte: Fórum, 2020.

MENDES, Laura Schertel; DONEDA, Danilo. Comentário à nova Lei de Proteção de Dados (Lei 13.709/2018): o novo paradigma da proteção de dados no Brasil. Revista de Direito do Consumidor, São Paulo, v. 27, n. 120, p. 555-587, nov./dez. 2018.

MENDES, Laura Schertel; DONEDA, Danilo. Reflexões iniciais sobre a nova lei geral de proteção de dados. Revista de Direito do Consumidor, São Paulo, v. 27, n. 120, p. 469-483, nov./dez. 2018.

MULHOLLAND, Caitlin. A LGPD e o fundamento da responsabilidade civil dos agentes de tratamento de dados pessoais: culpa ou risco? Disponível em: $<$ https://migalhas.uol.com.br/coluna/migalhas-de-responsabilidade-civil/329909/a-lgpd-e-ofundamento-da-responsabilidade-civil-dos-agentes-de-tr\%E2\%80\%A6>. Acesso em: 22 out. 2020 .

RODOTÀ, Stefano. A vida na sociedade da vigilância: a privacidade hoje. Maria Celina Bodin de Moraes (Org). Tradução: Danilo Doneda e Luciana Cabral Doneda. Rio de Janeiro: Renovar, 2008 .

SCHREIBER, Anderson. Novos paradigmas da responsabilidade civil: da erosão dos filtros da reparação à diluição dos danos. 6. ed. São Paulo: Atlas, 2015.

SOUZA, Carlos Affonso; PADRÃO, Vinicius. Incidentes de segurança e dever de notificação à luz da Lei Geral de Proteção de Dados Pessoais. In: SOUZA, Carlos Affonso; MAGRANI, Eduardo; SILVA, Priscilla (coord.). Caderno Especial: Lei Geral de Proteção de Dados (PGPD). São Paulo: Revista dos Tribunais, 2019.

SOUZA, Carlos Affonso Pereira de. Segurança e sigilo dos dados pessoais: primeiras impressões à luz da Lei 13.709/2018. In: FRAZÃO, Ana; OLIVA, Milena Donato; TEPEDINO, Gustavo (coord.). Lei Geral de Proteção de Dados Pessoais: e suas repercussões no Direito brasileiro. São Paulo: Revista dos Tribunais, 2019. p. 417-441.

TASSO, Fernando Antonio. A responsabilidade civil na Lei Geral de Proteção de Dados e sua 
interface com o Código Civil e o Código de Defesa do Consumidor. In: Cadernos jurídicos. São Paulo, Jan.-mar./2020, a. 21, n. 53, pp. 97-115.

TEIXEIRA, Tarcisio; ARMELIN, Ruth Maria Guerreiro da Fonseca. In: LIMA, Cíntia Rosa Pereira de. Comentários à lei geral de proteção de dados. São Paulo: Almedina, 2020.

TEPEDINO, Gustavo; TERRA, Aline de Miranda Valverde; GUEDES, Gisela Sampaio da Cruz. Fundamentos do direito civil: responsabilidade civil. [livro digital]. Rio de Janeiro: Forense, 2020, v.4.

Recebido em: 25/11/2021

$1^{\circ}$ Parecer em: 27/11/2021

$2^{\circ}$ Parecer em: 30/11/2021 